\title{
Environmental impact of corona virus (COVID-19) and nationwide lockdown in India; An alarm to future lockdown strategies.
}

Suresh Kumar ${ }^{\odot}$ Shishir Bhardwaj, Akash Singh, Hemant K Singh, Puneet Singh and Uzzwal K. Sharma

Geological Survey of India, Western Region, Jaipur

${ }^{\circ}$ Corresponding author email: sureshgeolbhu@gmail.com

\section{Abstract}

Global emerge of zoonotic novel coronavirus (COVID-19) became a pandemic and its effect to mankind is talk of the town now a days. This tiny, invisible enemy has affected every country in the world and almost every living directly or indirectly and nationwide complete lockdown has triggered a short-term environmental impact. Since 2003, coronavirus came into existence in the form of Severe Acute Respiratory Syndrome (SARS) and more evolved Middle East Respiratory Syndrome (MERS) in 2012. This time, at the end of December 2019, outbreak of novel coronavirus COVID-19 (also known as $\mathrm{SARS}-\mathrm{CoV}_{2}, \mathrm{nCoV}-2019$ ) draw attention as global health emergency. World Health Organization (WHO) report says that the outbreak of this virus is so immense, it has already affected $35,57,235$ people and caused death to 2,45,150 people worldwide and 46,433 Indians got affected with 1568 death as on $5^{\text {th }}$ May 2020 (2:00 am) and these numbers are increasing exponentially day by day. Virologist, micro-biologist and science community are hammering their head very hard to find out cure and vaccine against this powerful virus and to prevent mass demise of mankind. In order to curb the spread of COVID-19, Janta curfew on 22.03.2020 and nationwide complete lockdown was implemented in India for 21 days (phase-I, from 25.03.2020 to 14.04.2020) to stop community transmission of third stage, for 19 days (phase-II, 15.04.2020 to 03.05.2020) and 14 days (phase-III, 04.05.2020 to 17.05.2020) complete lockdown to minimize the community transmission effect. During complete lockdown and quarantine period a drastic change in Earth's atmosphere, including reduction in emission of greenhouse gases, air pollution ( $\sim 50 \%$ fall in air quality index), noise pollution, water pollution and solid waste pollution, have been recorded by government agencies as well as private agencies. In this paper we considered data of Janta curfew, phase-I and phase-II lockdown to link between geological and environmental aspect related to environmental impact due to emerge of COVID19 and massive reduction in pollution level during complete lockdown in India. We propose future lockdown strategies to minimise the emission of greenhouse gas by $100 \mathrm{Mt}$ to $200 \mathrm{Mt}$ (3.33\% to $6.66 \%$ ) of $\mathrm{GHG}_{\text {total }}$ per year by $2-4$ days per month nationwide lockdown or $\sim 70 \mathrm{Mt}$ to $\sim 140 \mathrm{Mt}$ $(2.33 \%$ to $4.66 \%)$ of $\mathrm{GHG}_{\text {total }}$ per year by $2-4$ days per month complete lockdown of energy sectors only.

Key words: Zoonotic, coronavirus, COVID-19, SARS, MERS, global health emergency, India, lockdown strategies. 


\section{Introduction}

China, first ranked greenhouse gas emitting nation, became the epicentre for the global emerges of zoonotic novel coronavirus (COVID-19) as first case was reported by the end of December- 2019, from Wuhan, a capital city of Hubei province in the People's Republic of China (Fan et, al. 2019). Outbreak of coronavirus have been reported by number of workers from past two decades. During 2003, coronavirus came into existence in the form of Severe Acute Respiratory Syndrome (SARS) and more evolved Middle East Respiratory Syndrome (MERS) in 2012 and SARS was also originated in China (Yi Fan et, al. 2019). Now, third one, a zoonotic novel coronavirus COVID-19 also known as SARS-CoV2, nCoV-2019, become global health emergency, has been reported first from China only (Peeri N C et, al. 2020). Past and present study on spread of coronavirus enhances the level of confidence between scientist and researchers that bats, a powerful reservoir hosts, is a connecting link between cross-species transmission of COVID-19 to human. The first case of COVID-19 was reported from Huanan sea food market of Wuhan where a variety of animals (terrestrial and sea animals) including bats were sold out as food in large quantity. World Health Organization (WHO, 2020) has announced a global health emergency citing its immense spread and uncontrollable community transmission of this zoonotic novel coronavirus (COVID-19). Virologist, micro-biologist and science community are exploring all the possible way, to find out cure and vaccine against this powerful virus and to save lives. This tiny, invisible enemy has affected every country worldwide and almost every living directly or indirectly. In order to curb spread of virus, a nationwide complete lockdown was implemented which has triggered a short-term environmental change.

India, the second most populous country in the world, has also got affected by the outbreak of COVID-19 and community transmission. WHO has reported 46433 COVID-19 confirmed cases with 1568 death in India as on $5^{\text {th }}$ May 2020, 2:00 am and these numbers are compounding each day (WHO, 2020). To minimize the spread and community transmission of third stage, Government of India has taken a very strict decision of nationwide complete lockdown which affected every citizen but not as much as COVID-19 could have. Prior to complete lockdown, one day 'Janta Curfew' was imposed on 22.03.2020 to analyse the seriousness of COVID-19. The complete lockdown was planned in three phases. Phase-I was implemented from 25.03.2020 to 14.04.2020 to identify the red-zone cities (cities with maximum COVID-19 cases) and to control third stage community transmission. Nationwide complete lockdown was further extended from 15.04.2020 to 03.05.2020 (phase-II) and from 04.05.2020 to 14.05.2020 (phase-III) to minimize the spread and to save maximum lives (Wikipedia, 2020). Due to combined effect of 'Janta Curfew' and phase-wise complete lockdown, India has witnessed an exponential fall in emission of greenhouse gases, air pollution $(\sim 50 \%$ fall in air 
quality index), noise pollution, water pollution and solid waste pollution which positively impacted the environment in such a short period. The complete lockdown and its enormous environmental impact, has open a new window to restructure the current environmental laws and act of Government of India to lower the pollution level for betterment of mankind. In this paper we have correlated air quality index (AQI) data of top three polluted cities of India during outbreak of COVID-19, during 'Janta Curfew' and during compete lockdown phase-I and phaseII. An attempt is also made to formulate future lockdown strategies to lower the pollution level.

\section{Link between pollution and virus}

Geologically, the pollution can be defined as the addition of any substance (solid, liquid, gas) or any form of energy (heat, sound, or radioactivity) to the Earth's atmosphere above permissible limit which directly affect environment, every living and human health. The major kinds of pollutions are air pollution (greenhouse gas emission), noise pollution, water pollution and solid waste pollution (NEERI, 2013). Troposphere, the lowest layer of Earth's atmosphere $(0 \mathrm{~km}$ to $12 \mathrm{~km})$, is the most affected layer by pollution as maximum number of living and most of the polluting agents have direct exposure to this layer. Ozone layer, part of upper troposphere and lower stratosphere ( $10 \mathrm{~km}$ to $50 \mathrm{~km})$, filters out sunlight wavelengths by ultraviolet wave absorption through ordinary oxygen and nitrogen in air which is one of the most important factor to effective life sustainability (Wikipedia, 2020). Low level ozone $\left(\mathrm{O}_{3}\right)$, in troposphere, is the resultant of higher rate of air pollution which is increasing in general and causing relatively higher temperatures and raising heat-related mortality during heat waves (Diem et al, 2010, 2017).

On the other hand, virus, a submicroscopic infectious agent that replicates only inside the living cells of an organism, can infect all types of life forms viz. animals, plants and microorganisms (Koonin et, al. 20016). Researcher has already established a direct link between pollution and virus by lab experiment (Salk and Gori, 1960, Mumford et, al 1987, Gerba et, al. 2017 and many more). Virus aggregation-disaggregation is a complex process and varies with environmental circumstances (Gerba and Betancourt, 2017). It has also been proved that pollution in any form is directly concerned to human health. More precisely, air pollution (higher AQI) has both acute and chronic effects on human health. It affects number of different systems and organs resulted in minor upper respiratory irritation to chronic respiratory and heart disease, lung cancer and acute respiratory infections (Kampa and Castanas, 2008). In nut cell, human coronaviruses, including present COVID-19, which causes lethal respiratory tract infection are also related to level of air pollution. Although, more research is needed in respect of COVID-19 aggregation-disaggregation in given set of environmental circumstances by actual experimental data. 


\section{Pollution in India}

Pollution is the introduction of any harmful material into the environment which has negative impact on living organism. These harmful materials are called pollutants. The major pollutions are air pollution, noise pollution, water pollution and solid waste pollution in order of abundance. Pollutions are the largest environmental cause of disease and premature death in nation and worldwide now a days. Diseases caused by pollutions were responsible for an estimated 9 million premature deaths in 2015, nearly $16 \%$ of all deaths worldwide (Landrigan et al., 2017).

The Air (Prevention and Control of Pollution) Act, 1981 describe, air pollution is the presence of any solid, liquid, or gaseous substances in the atmosphere above permissible limit which is injurious to human health and other living creatures or plants or land or environment. It is mainly due to population explosion, rapid industrialization, deforestation, unplanned urbanization and unbalanced scientific advancement. Air pollution kills an estimated seven million people worldwide every year (WHO, 2018). WHO emphasizes that 9 out of 10 people breathe air containing high levels of pollutants. The most commonly contributing sources for air pollution are vehicles, manufacturing and electricity generation industries, construction activities, road dust, waste burning, combustion of oil, coal, biomass in the households and marine/sea salt. India for years has been striving to improve its air quality in urban areas, which takes a massive toll on the health of millions of its residents. Air pollution was the second largest risk factor contributing to disease burden in India after malnutrition in 2016 (India State-Level Disease Burden Initiative Air Pollution Collaborators, 2019).

\subsection{Air Quality Index (AQI)}

Quality air is prime source for sustenance of life on Earth. Air quality is determined to understand the trend of pollution which mainly includes particulate matter $\left(\mathrm{PM}_{2.5}\right.$ and $\left.\mathrm{PM}_{10}\right)$, $\mathrm{SO}_{2}, \mathrm{NO}_{2}, \mathrm{CO}, \mathrm{O}_{3}, \mathrm{NH}_{3}$, and $\mathrm{Pb}$. Air pollution has maximum impact on environment and public health and its quality can be represented by measuring concentration of pollutants with standard levels. Air pollution is root cause to premature mortality and disease burden globally (Cohen AJ et al., 2017). An estimated 4.2 million premature deaths globally are linked to ambient air pollution, mainly from heart disease, stroke, chronic obstructive pulmonary disease, lung cancer, and acute respiratory infections in children (WHO, 2018). PM is currently considered to be the best indicator for health effects of ambient air pollution (Burnett et al., 2014). PM is capable of penetrating deep into lung passageways and entering the bloodstream causing cardiovascular, cerebrovascular and respiratory impacts. 
The World Health Organization (WHO, 2016) released its global air pollution database in Geneva and India constitutes 14 out of the 15 most polluted cities in the world in terms of particulate matter PM2.5 levels. At current levels, $99.9 \%$ of the Indian population is estimated to live in areas where the World Health Organization (WHO) Air Quality Guideline of $10 \mu \mathrm{gm}-3$ was exceeded (Venkataraman et al., 2018). Increased air pollution levels have reduced average life expectancy by 1.7 years in India (India State-Level Disease Burden Initiative Air Pollution Collaborators, 2019).

Government of India, in 2015, together with IIT Kanpur launched the National Air Quality Index. Subsequently in 2019, India launched 'The National Clean Air Programme' with tentative national target of 20\%-30\% reduction in PM2.5 and PM10 concentrations by 2024, considering 2017 as the base year for comparison. Central Pollution Control Board (CPCB) along with State Pollution Control Boards has been operating National Air Monitoring Program (NAMP) covering 240 cities of India to measure level of air pollution hourly (CPCB, 2020). Air Quality Index (AQI) is a tool for effective dissemination of air quality information to common people for awareness of air pollution level in the country. An AQI is defined as an overall scheme that transforms weighted values of individual air pollution related parameters $\left(\mathrm{SO}_{2}, \mathrm{CO}\right.$, visibility, etc.) into a single number or set of numbers. As per CPCB norms there are six AQI categories namely good, satisfactory, moderately polluted, poor, very poor, and severe (Table 1). Each category is based on ambient concentration values in air pollutants and their likely health impacts (health breakpoints). AQ sub-index and health breakpoints are evolved for eight pollutants ( $\mathrm{PM}_{10}, \mathrm{PM}_{2.5}, \mathrm{NO}_{2}, \mathrm{SO}_{2}, \mathrm{CO}, \mathrm{O}_{3}, \mathrm{NH}_{3}$, and $\mathrm{Pb}$ ) for which short-term (up to 24-hours) National Ambient Air Quality Standards are prescribed.

In order to understand the environmental impact due to outbreak of corona virus (COVID-19) and complete lockdown in India during Janta curfew (22.03.2020), lockdown phase-I (24.03 2020 to 14.04.2020) and lockdown phase-II (15.04 2020 to 03.05.2020), AQI data of top three polluted cities in India viz; Kanpur, Faridabad and Varanasi (WHO, 2018) were analysed and the result on air quality is happen to be recognizably improved. For better comparison, AQI data of same period in 2019 was also compared with present scenario (figure 1). AQI data of same period (January first week) during the year 2019 and 2020 was moderate to severe and during $22^{\text {nd }}$ March to $3^{\text {rd }}$ May, 2019 recorded moderate to poor impact on human health. However, during Janta curfew, a significant drop in AQI ( 50\%) can be seen and a drastic drop in AQI value is recorded in top three polluted cities during lockdown phase-I and lockdown phase-II (figure 2A \& B, table 2). In nut shell, AQI in India fall between good-severe to goodsatisfactory range for more than $90 \%$ cities in India due to nationwide lockdown (figure 2C). It is conclusive that nationwide lockdown considerably improved air quality and lowered pollution 
level in India. Lockdown Strategy Models (LSM-1 \& LSM-2) may be considered in future to minimize the environmental impact on nature and public health.

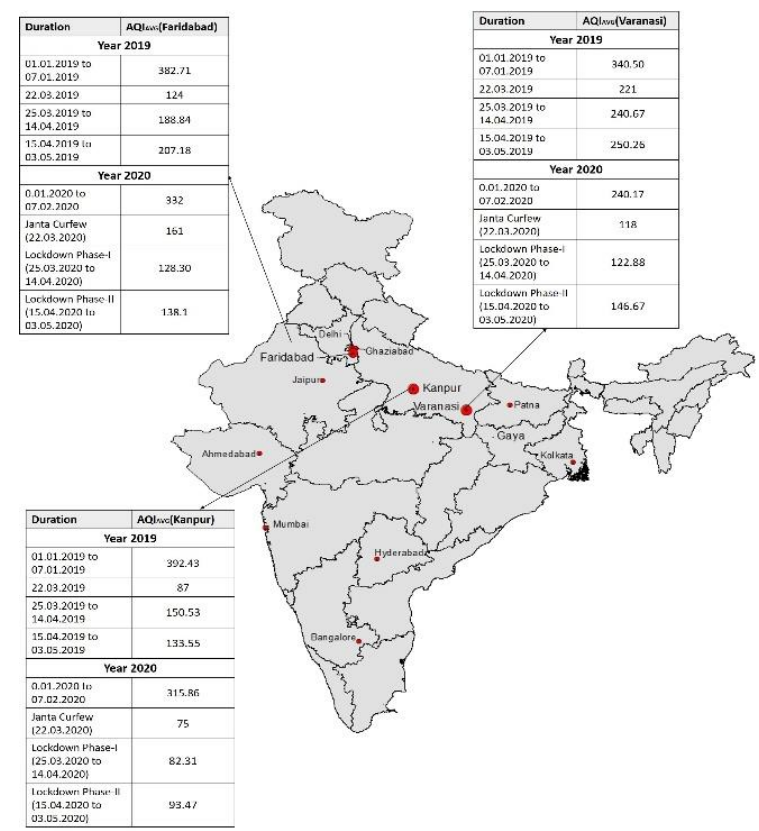

Figure 1: Status of AQI of top three most polluted city of India (WHO, 2018) during outbreak of COVID-19, Janta curfew, lockdown phase-I and phase-II and for similar period in the year 2019.
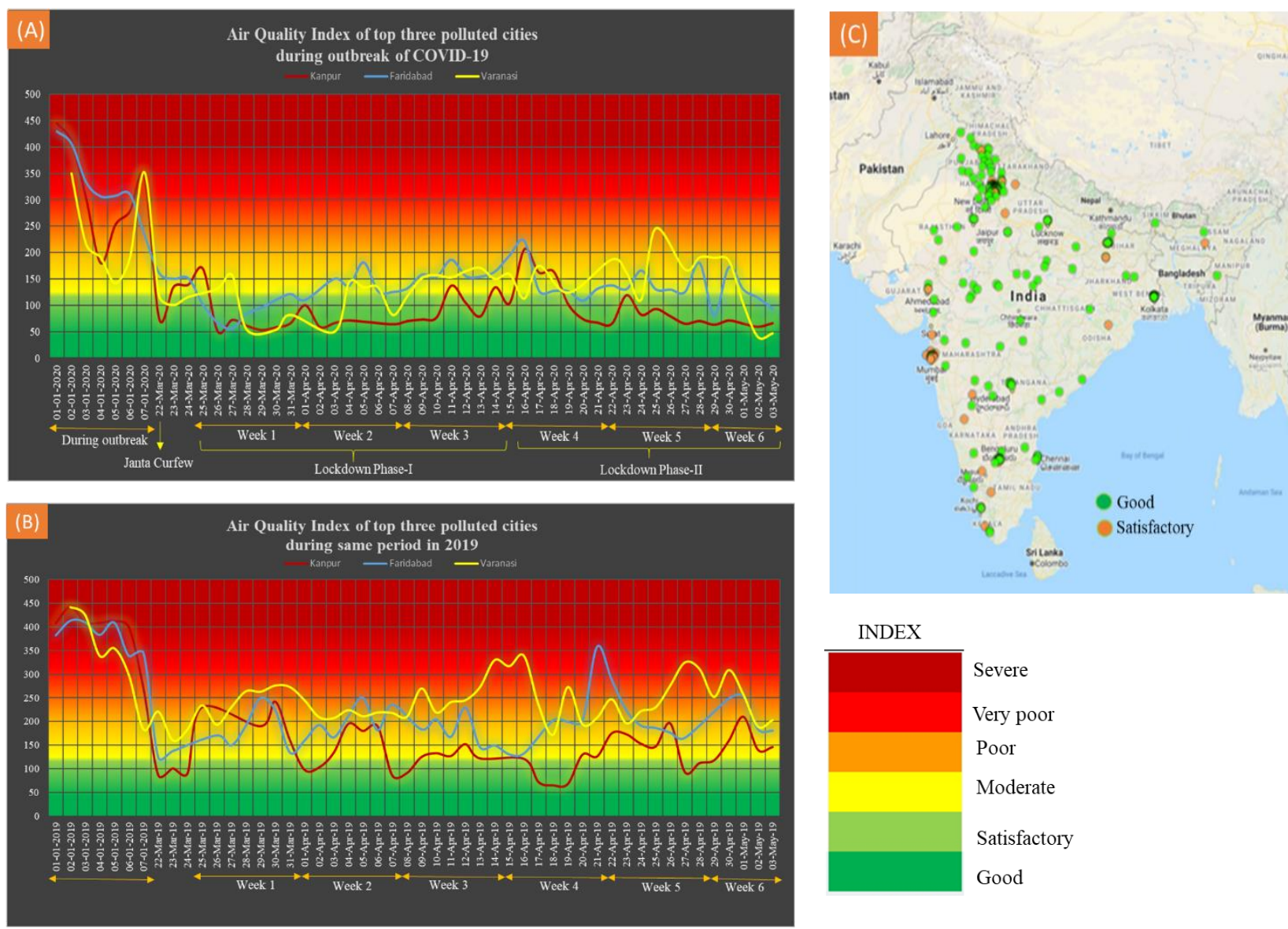

Figure 2: (A) AQI (18:00hrs) data (CPCB, 2020) of top polluted cities (WHO, 2018) during outbreak of COVID-19, Janta curfew, lockdown phase-I and phase-II. (B) AQI data of same period during previous year 2019. (C) Map showing fall of AQI from good-severe to good-satisfactory range for more than $90 \%$ cities in India during the peak of lockdown (15.04.2020, 19:00hrs). 


\subsection{Noise pollution in India}

Rapid and unplanned urbanization has amplified to many health challenges that includes environmental air and noise pollution. Noise, the unwanted sound, emitted from any source above permissible limit and harmful to health is defined as noise pollution. The environmental noise is accepted as a biggest threat to human kind as it is more intense and widespread than ever before because of its exponential growth in the urban areas. From road to air traffic, humans are that much dependent on machinery that there is no way to escape from noise pollution. Noise is regarded as a pollutant under the Prevention and Control of Pollution Act, 1981 of India (MoEF 1981 Act). The World Health Organization (WHO) estimates that $10 \%$ of the world population is exposed to sound pressure levels that could potentially causes noise induced hearing loss ( $\mathrm{N}$ (Oishi and Schacht, 2011; Basner et al., 2014). Motor vehicles are the main sources of urban noise pollution contributing about 55\% to the total noise (Banerjee et al., 2008; Pandya and Dharmadhikari, 2010; Sinha and Sridharan, 2003). Population growth of vehicle and transportation has led to noise pollution and associated health effects which can cause both shortterm and long-term physiological, psychological and performance-related effects in India as well as worldwide.

Central Pollution Control Board established a pilot project of National Ambient Noise Monitoring Network $(N A N M N)$ for monitoring, analysing and disseminating noise levels data/information to the public. Initially, the project covered 35 locations in seven metro cities (Delhi, Mumbai, Kolkata, Chennai, Lucknow, Hyderabad and Bangalore) of India. The installation of 35 more stations (November, 2014) in the same seven cities enhanced the scope of this project. Presently, it covers 70 locations in seven metro cities of India which is a unique and one of the largest noise monitoring networks of its kind across the world.

We analysed, the ambient noise levels: $\mathrm{NL}_{\text {day }}$ (day equivalent level) and $\mathrm{NL}_{\text {night }}$ (night equivalent level) for all the major cities and presenting ITO, Delhi site (a commercial area) noise level. The comparative study between present level to the ambient noise standard indicates noise level for $\mathrm{NL}_{\text {day }}$ and $\mathrm{NL}_{\text {night }}$ is very high (above permissible limit) in ITO, Delhi with marginal decrease in ambient noise level since the past five years (figure $3 \mathrm{~A} \& \mathrm{~B}$ ). The ambient noise levels have decreased for ITO site by $1 \mathrm{~dB}(\mathrm{~A})$ for $\mathrm{NL}_{\text {day }}$ and $2.8 \mathrm{~dB}(\mathrm{~A})$ for $N L_{\text {night }}$ from past five years. The data on ambient noise levels at ITO, Delhi for 2018 indicates an average increase by $8.1 \mathrm{~dB}(\mathrm{~A})$ for $\mathrm{NL}_{\text {day }}$ and $14.8 \mathrm{~dB}(\mathrm{~A})$ for $\mathrm{NL}_{\text {night }}$ from standard. During the month of October, November and December of 2018, the ambient noise level for day is increased compared to rest months, showed an increase in the rate of noise pollution. It can be observed that ITO site in Delhi region does not meets the ambient noise standards. There is an average $\sim 50 \%$ reduction of pollution level during Janta curfew, phase-I lockdown and phase-II lockdown and we expect same level of reduction for noise pollution also. 

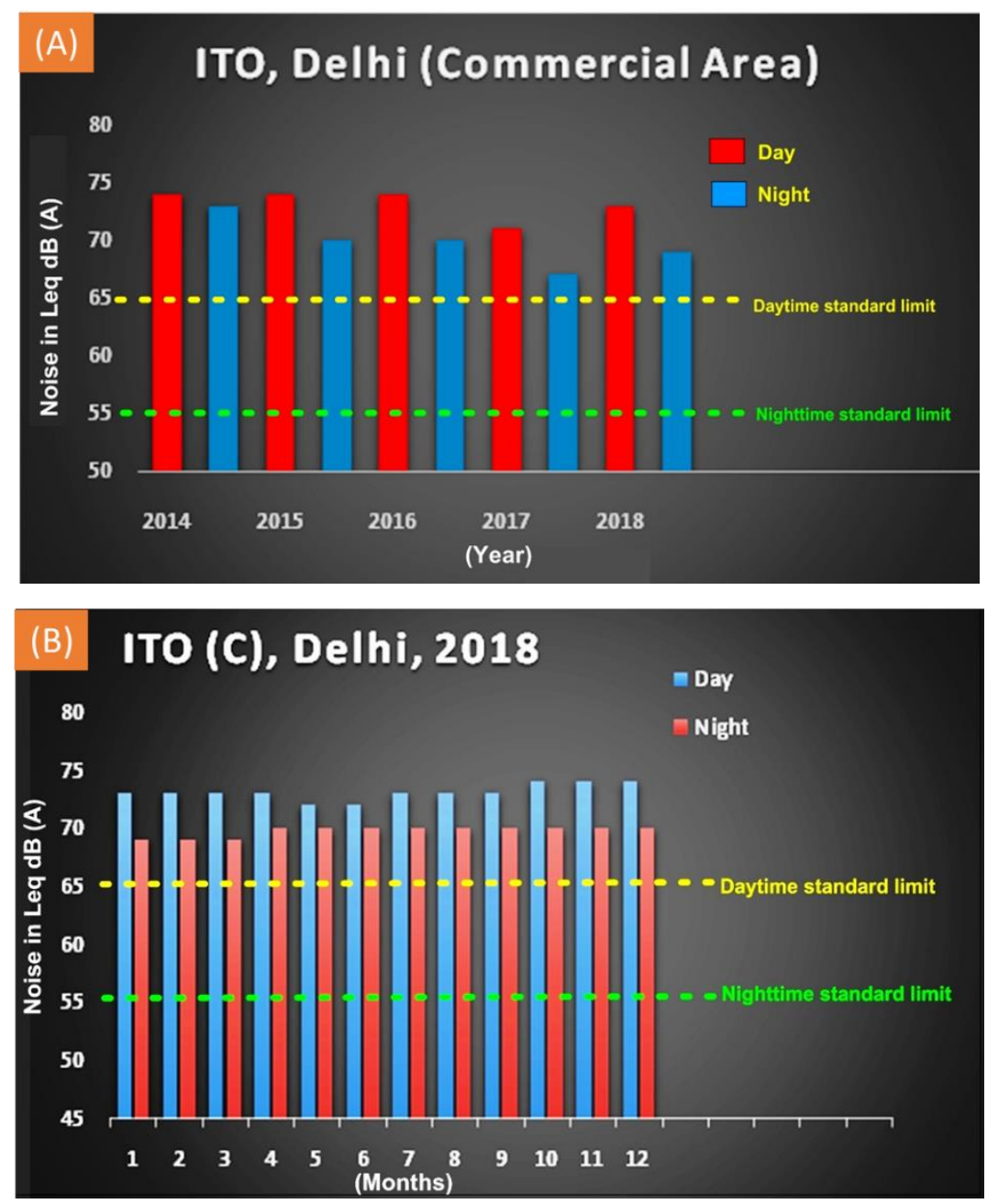

Figure 3. (A) Yearly variation in ambient noise levels during $\mathrm{NL}_{\text {day }}$ and $\mathrm{NL}_{\text {night }}$ for ITO, Delhi commercial area. (B) Monthly variation in ambient noise levels during $\mathrm{NL}_{\text {day }}$ and $\mathrm{NL}_{\text {night }}$ during 2018.

\section{Future lockdown strategies}

The environmental impact of nationwide complete lockdown during outbreak of COVID-19 has opened a wide window to reform present environmental safety rules in India. Though, the nationwide lockdown will certainly affect economic growth, GDP and every individual directly but proper strategy can minimise the loss and maximize the environmental impact for betterment. Environmental safety is directly related to human health and sustainable development of any country. There are number of pollution agents viz. air pollution (greenhouse gas emission), noise pollution, water pollution and solid waste pollution (NEERI, 2013), which affect environment and human health up to a great extent. Among them, air pollution plays major role to the environmental impact. We have considered air pollution (greenhouse gas emission) as a controlling factor for proposing future lockdown strategy models (LSM) in this paper. The models are formulated based on environmental impact of lockdowns in India but can be useful worldwide in near future. Central Pollution Control Board (CPCB, 2020, https://www.cpcb.nic.in) and Indian Meteorological Department (IMD, 2020, 
https://mausam.imd.gov.in) online AQI data and WRI CAIT data on GHG emission were utilized to formulate future lockdown strategy in India.

World Resources Institute Climate Analysis Indicators Tool (WRI CAIT, 2017) data indicates that India in 2014, emitted a total of $3163.7 \mathrm{Mt}\left(\mathrm{MtCO}_{2} \mathrm{e}\right)$ of greenhouse gas (GHG) from energy sector $(68.7 \%)$, agriculture (19.6\%), industrial processes $(6 \%)$, land use change and forestry $3.8 \%$ and waste $(1.9 \%$ ) respectively of total emission (figure 4 A \& B). Greenhouse gas emission in India is increasing every year. According to WRI CAIT, India's GHG emissions (Gupta and Singh, 2016) increased by $1980.65 \mathrm{MtCO}_{2} \mathrm{e}$ from the year $1990\left(1,183.05 \mathrm{MtCO}_{2} \mathrm{e}\right)$ to 2014 (3163.7 $\left.\mathrm{MtCO}_{2} \mathrm{e}\right)$ and energy and agriculture sectors were the two highest emitting sectors. India has produced 3177.2 Mt and 3235.66 $\mathrm{Mt}$ of $\mathrm{GHG}_{(\text {total })}$ in the year 2015 and 2016 respectively. WRI CAIT available data of last five year from 2012 to 2016 for $\mathrm{GHG}_{(\text {total }}$ emission in India indicates that an average of $3000 \mathrm{Mt}$ of $\mathrm{GHG}_{(\text {total })}$ per year is being emitted by all sectors mentioned above.
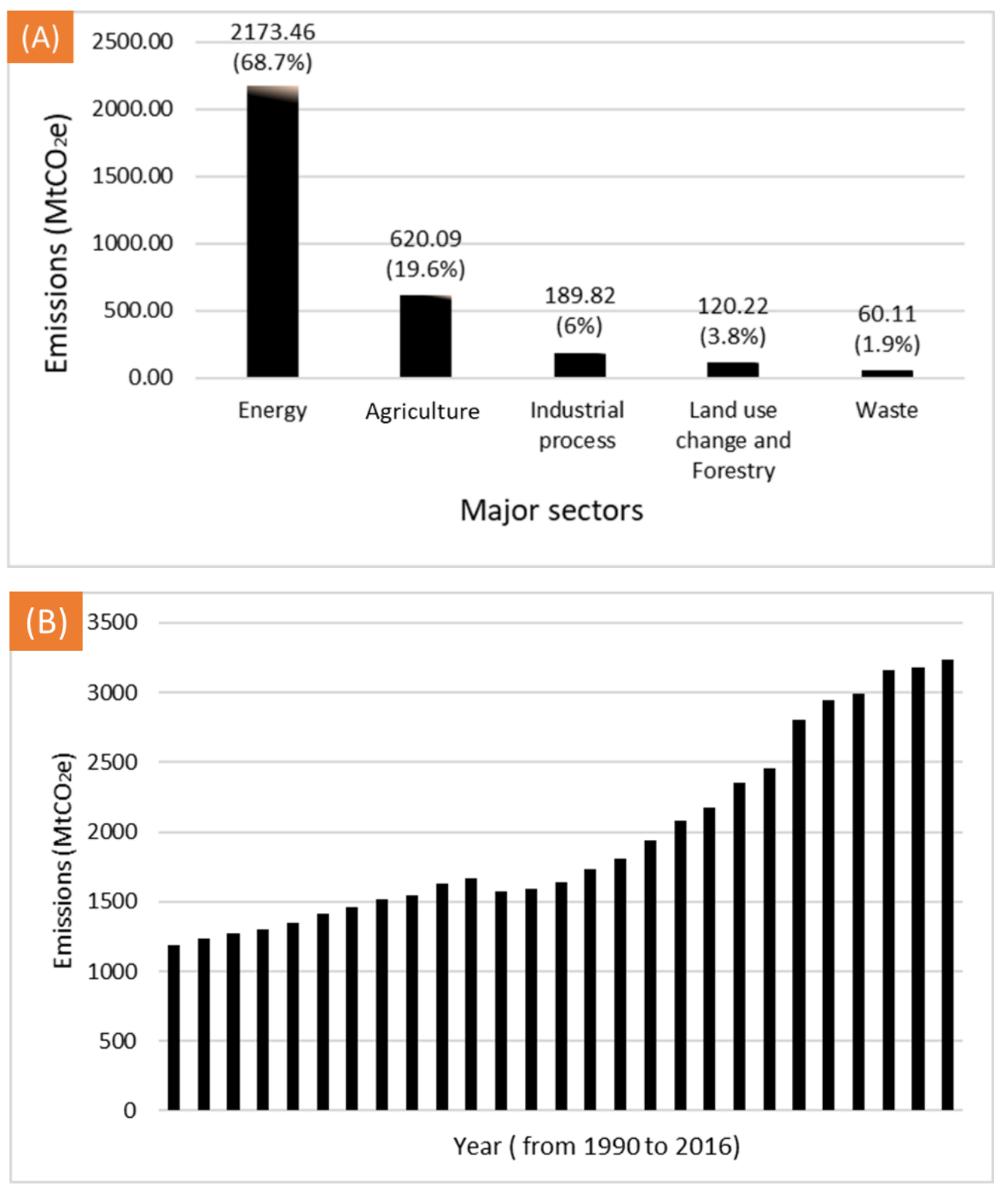

Figure 4 (A) Greenhouse gas emission in India by sector including percent of total. (B) Greenhouse gas emission in India year wise (WRI CAIT, 2017). 
Data on AQI of most polluted cities in India indicates substantial decrease $(\sim 50 \%)$ in pollution level and GHG emission during Janta curfew, phase-I lockdown and phase-II lockdown in India. The major sectors, producing extensive air pollution (GHG emission) are transport, industries, power plants, construction activities, biomass \& refuse burning, road dust suspension, were completely locked down. This resulted in air quality improvement across the nation. We have calculated GHG emission per day (approx.) in India with the formula mentioned below (figure 5).

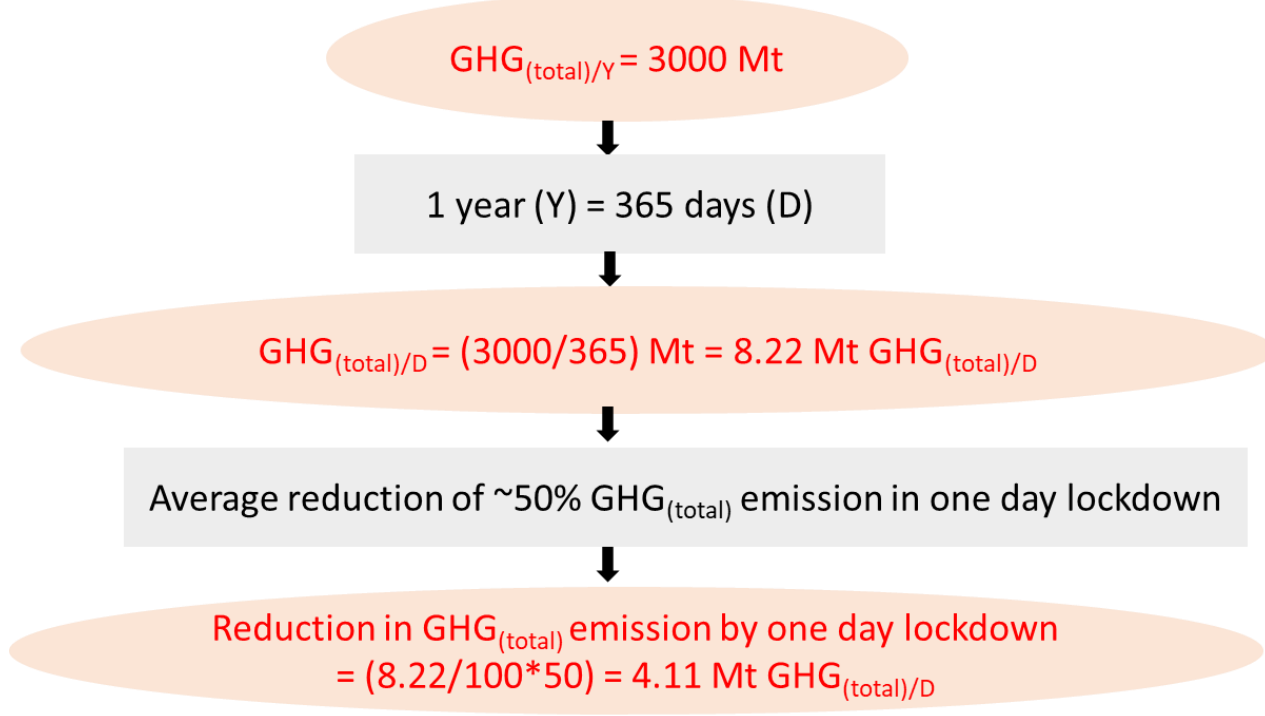

Figure 5. Assessments of $\mathrm{GHG}_{(\text {total }}$ reduction in India by one day complete lockdown.

\subsection{Lockdown Strategy Model (LSM-1)}

LSM-1 model is based on environmental impact due to nationwide complete lockdown in present circumstances of COVID-19 and formulated to minimise the emission of greenhouse gas in the country. Most of the air pollution producing anthropogenic sources (industrial as well as commercial) were completely locked down and its impact on environment indicates massive improvement of AQI in most of the cities (CPCB, 2020; IMD, 2020). AQI reduces by almost $50 \%$ and ranges between good-severe to good-satisfactory (figure 2C). India produces an average of $3000 \mathrm{Mt} \mathrm{GHG}_{\text {total }}$ in the past five years (WRI CAIT, 2017) and almost 8.22 Mt $\mathrm{GHG}_{\text {total }}$ per day (figure 5). Nationwide complete lockdown reduces almost $\sim 50 \%$ air pollution in one day $(\mathrm{CPCB}, 2020)$ suggests reduction of $4.11 \mathrm{Mt} \mathrm{GHG}_{\mathrm{total}}$ emission per day. We propose future lockdown strategy to minimize the $\mathrm{GHG}_{\text {total }}$ emission which is directly related to public health. We suggest nationwide complete lockdown once in every 15 days will save about 100Mt (3.33\%) $\mathrm{GHG}_{\text {total }}$ emission per year and 2 days continuous lockdown in every 15 days or once in a week complete lockdown will save about 200Mt (6.66\%) $\mathrm{GHG}_{\text {total }}$ emission per year (figure $6)$. 


\subsection{Lockdown Strategy Model (LSM-2)}

This model is based on nationwide complete lockdown of energy sector only. As per WRI CAIT, 2017 data India in 2014, emitted a total of 3163.7 Mt $\left(\mathrm{MtCO}_{2} \mathrm{e}\right)$ of greenhouse gas (GHG) and energy sector contributed almost $70 \%$ of the total. We suggest nationwide complete lockdown of energy sector once in every 15 days will save about $70 \mathrm{Mt}(2.33 \%) \mathrm{GHG}_{\text {total }}$ emission per year and 2 days continuous lockdown in every 15 days or once in a week complete lockdown of energy sector will save about 140Mt (4.66\%) $\mathrm{GHG}_{\text {total }}$ emission per year (figure 6). Although, additional and effective future strategies are expected with respect to minimising the economic loss and maximizing the environmental impact for betterment by more research.

\subsection{Some other strategy}

Trees are like mask to save humans from air pollution. Afforestation, the establishment of a forest or forestation in an area where no previous tree cover was recorded, is the need of the hour. Government and non-governmental organizations directly engage in programs of afforestation to create forests and increase carbon capture but a strict rule, similar to COVID-19, is needed to percolate at individual levels. In wake of COVID-19, it can be understood that awareness can be generated in mass regarding environmental as well as health issues. Similar to COVID-19 prevention and measures, India need to warn every individual regarding seriousness of this another unseen enemy called pollution. Mandatory plantation in housing and firm land with ensuring strict compliance by government will be helpful in achieving this goal This movement can be exploited for formulation and implementation of future policy. Afforestation and forestation help in carbon fixation and GHG reduction which are directly related to public health. Similar strategy with strict rule is also required for minimizing pollution levels, GHG emission and maximizing environmental impact for betterment.

\section{Discussion}

\subsection{Assessments of lockdown effect on human}

A zoonotic coronavirus COVID-19 has been a pandemic worldwide since December 2019. The outbreak of COVID-19 and related number of human deaths worldwide became a serious issue with question marks. Virologist, micro-biologist, cell-biologist and researchers are hammering their head very hard to find out cure and vaccine against this powerful invisible coronavirus COVID-19 to stop mass extinction of mankind. Government of India declared a nationwide lockdown for 21 days (phase-I, 24.04.2020 to 14.04.2020) and extended for 19 days (phase-II, from 15.04.2020 to 03.05.2029), for 14 days (phase-III, from 04.05.2020 to 17.05.2029), as a preventive measure against the COVID-19 pandemic in India. The lockdown 
was imposed when COVID-19 confirmed cases reached 500 to stop further community transmission (Gettleman and Schultz, 2020). This resulted in thousands of people emigrated out of major Indian cities, as they became jobless after the lockdown (Priyali and Ben, 2020). At the same time the Indian economy is expected to lose over ₹32,000 crore per day during the lockdown (The Hindu Business Line, 2020). This has affected every individual directly or indirectly up to a great extent.

\subsection{Assessments of lockdown impact on environment}

Global warming and greenhouse gas emission is another invisible future pandemic which need extra precautions for environmental safety and public health. India, the second largest populous country also witnessed this present pandemic and 46433 Indians got affected with 1568 death as on $5^{\text {th }}$ May 2020 (2:00 am) and these numbers are increasing every day. Spread of COVID-19 and related human death resulted in nationwide complete lockdown to stop community transmission of third stage. During complete lockdown and quarantine period of Janta curfew, lockdown phase-I and lockdown phase-II, a drastic change in Earth's atmosphere and environment was recorded (CPCB, 2020, IMD, 2020) and pollution level reduced by 50\% approximately (CPCB, 2020). The environmental impact of nationwide complete lockdown during outbreak of COVID-19 has open a wide window to reassess future sustainability. We suggests LSM-1 and LSM-2 can be very effective for future lockdown strategies to minimise the emission of greenhouse gas by $\sim 100 \mathrm{Mt}$ to $\sim 200 \mathrm{Mt}$ (3.33\% to 6.66\%) of $\mathrm{GHG}_{\text {total }}$ per year by 2-4 days per month nationwide lockdown or $\sim 70 \mathrm{Mt}$ to $\sim 140 \mathrm{Mt}(2.33 \%$ to $4.66 \%)$ of $\mathrm{GHG}_{\text {total }}$ per year by 2-4 days per month complete lockdown of energy sectors only.

\section{Conclusions}

- This is a quantitative approach to minimise greenhouse gas emission and other pollutions in country after outbreak of COVID-19.

- Public health is directly related to pollution level and minimizing pollution level in country is need of the hour. The environmental impact of nationwide complete lockdown during outbreak of COVID-19 was very significant for reducing pollution levels includes air pollution (GHG emission), noise pollution, water pollution and solid waste pollution. Nationwide lockdown with proper planning is very effective process which can be implemented strictly for environmental seftey and lowering the pollution levels.

- We propose future lockdown strategy models for reducing greenhouse gas emission. The LSM-1 model suggests nationwide complete lockdown once in every 15 days which will save about $100 \mathrm{Mt}(3.33 \%) \mathrm{GHG}_{\text {total }}$ emission per year and 2 days continuous lockdown in every 15 days or once in a week complete lockdown will save about $200 \mathrm{Mt}(6.66 \%) \mathrm{GHG}_{\text {total }}$ emission per year 
- The LSM-2 model suggests nationwide complete lockdown of energy sector only, once in every 15 days will save about $70 \mathrm{Mt}(2.33 \%) \mathrm{GHG}_{\text {total }}$ emission per year and 2 days continuous lockdown in every 15 days or once in a week complete lockdown of energy sector will save about $140 \mathrm{Mt}(4.66 \%) \mathrm{GHG}_{\text {total }}$ emission per year.

- Afforestation and forestation help in carbon fixation and GHG reduction up to a great extent which are directly related to public health. Mandatory plantation in housing and firm land with ensuring strict compliance by government will be helpful in achieving this goal. This movement can be achieved by formulation, implementation and strict compliance of future strategy. 


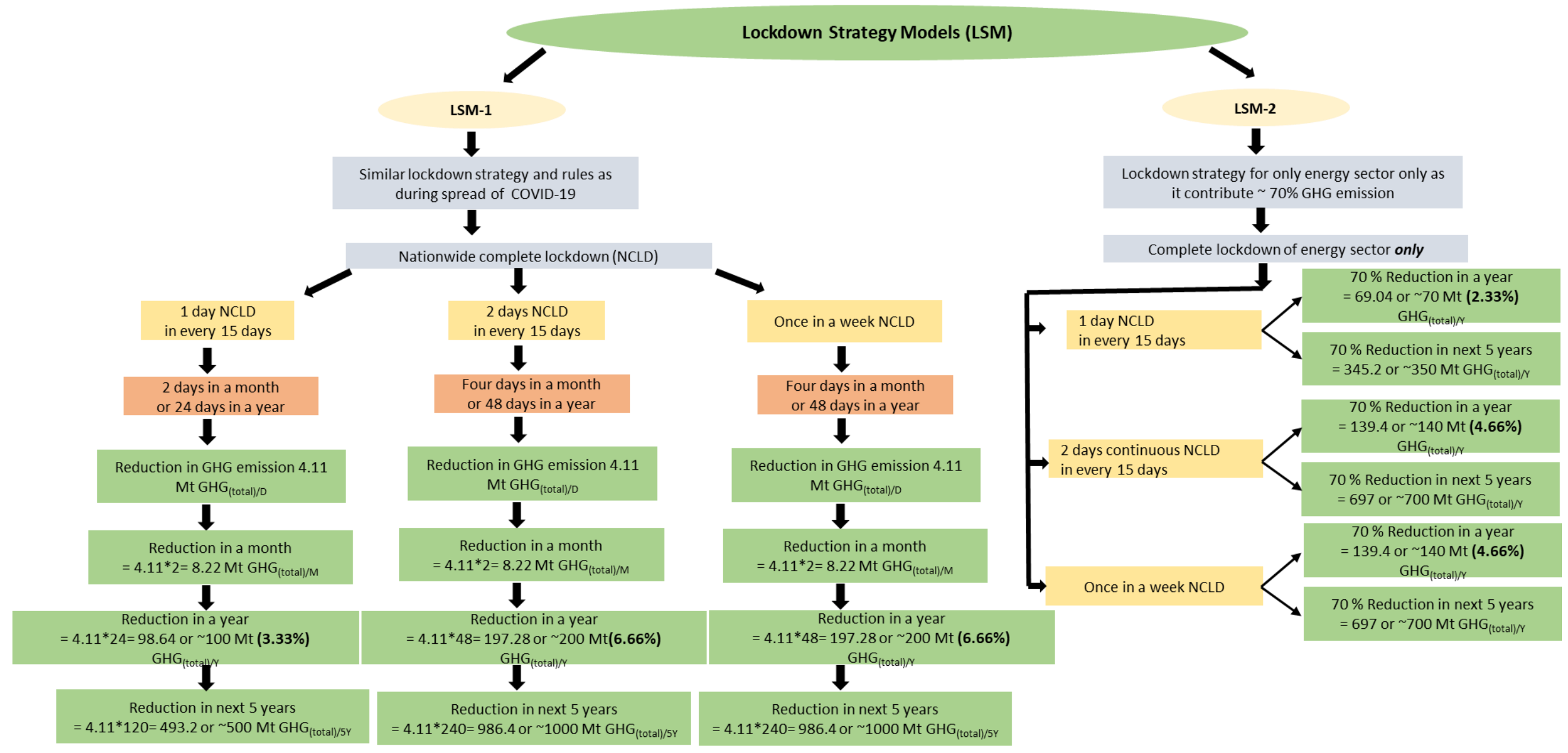

\section{$\downarrow$} days in a yea in GHG emission 4.1 4 or $100 \mathrm{Mt}(3.33 \%)$

Reduction in next 5 years $=4.11 * 120=493.2$ or $\sim 500 \mathrm{Mt} \mathrm{GHG}_{(\text {total)/5Y }}$
Figure 6. The proposed future lockdown strategy to minimise greenhouse gas (GHG) emissions in country.

\section{rostar}

\section{Lockdown Strategy Models (LSM)}

$70 \%$ GHG emission

\section{Therg sector only} 1

$70 \%$ Reduction in next 5 years $=345.2$ or $~ 350 \mathrm{Mt} \mathrm{GHG}_{(\text {total) } /}$

$70 \%$ Reduction in a year . 4 or $140 \mathrm{Mt}(4.66 \%)$

$\%$ Reduction in next 5 years $=697$ or $\sim 700 \mathrm{Mt} \mathrm{GHG}_{\text {(total)/ }}$ $70 \%$ Reduction in a year 4 or $140 \mathrm{Mt}(4.66 \%)$ \% Reduction in next 5 years
$=697$ or $~ 700 \mathrm{Mt} \mathrm{GHG}$
$($ total) $/ \mathrm{r}$

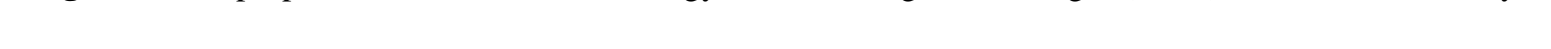




\begin{tabular}{|c|c|c|c|c|c|c|c|c|c|}
\hline $\begin{array}{l}\text { AQI } \\
\text { Category } \\
\text { (Range) }\end{array}$ & $\begin{array}{l}\text { PM10 } \\
\text { 24-hr }\end{array}$ & $\begin{array}{l}\text { PM2.5 } \\
\text { 24-hr }\end{array}$ & $\begin{array}{l}\text { NO2 } \\
\text { 24-hr }\end{array}$ & $\begin{array}{l}\text { O3 } \\
\text { 8-hr }\end{array}$ & $\begin{array}{l}\text { CO } \\
8-\mathrm{hr} \\
(\mathrm{mg} / \mathrm{m3})\end{array}$ & $\begin{array}{l}\mathrm{SO}_{2} \\
\text { 24-hr }\end{array}$ & $\begin{array}{l}\mathrm{NH}_{3} \\
24-\mathrm{hr}\end{array}$ & $\begin{array}{l}\mathrm{Pb} \\
\text { 24-hr }\end{array}$ & Impact on public health \\
\hline Good (0-50) & $0-50$ & $0-30$ & $0-40$ & $0-50$ & $0-1.0$ & $0-40$ & $0-200$ & $0-0.5$ & Minimal Impact \\
\hline $\begin{array}{l}\text { Satisfactory } \\
(51-100)\end{array}$ & $51-100$ & $31-60$ & $41-80$ & $51-100$ & $1.1-2.0$ & $41-80$ & $201-400$ & $0.5-1.0$ & May cause minor breathing discomfort to sensitive people. \\
\hline $\begin{array}{l}\text { Moderately } \\
\text { polluted } \\
(101-200)\end{array}$ & $101-250$ & $61-90$ & $81-180$ & $101-168$ & $2.1-10$ & $81-380$ & $401-800$ & $1.1-2.0$ & $\begin{array}{l}\text { May cause breathing discomfort to people with lung disease such } \\
\text { as asthma, and discomfort to people with heart disease, children } \\
\text { and older adults. }\end{array}$ \\
\hline $\begin{array}{l}\text { Poor } \\
(201-300)\end{array}$ & $251-350$ & $91-120$ & $181-280$ & $169-208$ & $10-17$ & $381-800$ & $801-1200$ & $2.1-3.0$ & $\begin{array}{l}\text { May cause breathing discomfort to people on prolonged exposure, } \\
\text { and discomfort to people with heart disease. }\end{array}$ \\
\hline $\begin{array}{l}\text { Very poor } \\
(301-400)\end{array}$ & $351-430$ & $121-250$ & $281-400$ & $209-748$ & $17-34$ & $801-1600$ & $\begin{array}{l}1200- \\
1800\end{array}$ & $3.1-3.5$ & $\begin{array}{l}\text { May cause respiratory illness to the people on prolonged exposure. } \\
\text { Effect may be more pronounced in people with lung and heart } \\
\text { diseases. }\end{array}$ \\
\hline $\begin{array}{l}\text { Severe } \\
(401-500)\end{array}$ & $430+$ & $250+$ & $400+$ & $748+$ & $34+$ & $1600+$ & $1800+$ & $3.5+$ & $\begin{array}{l}\text { May cause respiratory effects even on healthy people and serious } \\
\text { health impacts on people with lung/heart diseases. The health } \\
\text { impacts may be experienced even during light physical activity. }\end{array}$ \\
\hline
\end{tabular}

Table 1: AQI Category, Pollutants and Health Breakpoints with permissible limits and their impact on public health (CPCB, annual report, 2018).

\begin{tabular}{|c|c|c|c|c|c|c|c|}
\hline Duration & \multirow[t]{2}{*}{$\begin{array}{l}\text { AQIavg } \\
\text { Kanpur }\end{array}$} & \multirow[t]{2}{*}{$\begin{array}{l}\text { AQI }{ }_{\text {avg }} \\
\text { Faridabad }\end{array}$} & \multirow[t]{2}{*}{$\begin{array}{l}\text { AQIavg } \\
\text { Varanasi }\end{array}$} & Duration & \multirow[t]{2}{*}{$\begin{array}{l}\text { AQIavg } \\
\text { Kanpur }\end{array}$} & \multirow[t]{2}{*}{$\begin{array}{l}\text { AQI }{ }_{\text {avg }} \\
\text { Faridabad }\end{array}$} & \multirow[t]{2}{*}{$\begin{array}{l}\text { AQI } \\
\text { Varg } \\
\text { Varanasi }\end{array}$} \\
\hline Year 2020 & & & & Year 2019 & & & \\
\hline $\begin{array}{l}\text { During outbreak of COVID- } \\
19(1.04 .2020 \text { to } 7.04 .2020)\end{array}$ & 316 & 332 & 240 & $\begin{array}{l}\text { From 1.04.2020 to } \\
7.04 .2020\end{array}$ & 392 & 383 & 340 \\
\hline $\begin{array}{l}\text { Janta Curfew } \\
(22.03 .2020)\end{array}$ & 75 & 161 & 118 & On 22.03.2020 & 87 & 124 & 221 \\
\hline $\begin{array}{l}\text { Lockdown phase-I } \\
(24.03 .2020 \text { to } 14.04 .2020)\end{array}$ & 85 & 129 & 122 & $\begin{array}{l}\text { From } 25.03 .2020 \text { to } \\
14.04 .2020)\end{array}$ & 147 & 189 & 238 \\
\hline $\begin{array}{l}\text { Lockdown phase-II } \\
(15.04 .2020 \text { to } 03.05 .2020)\end{array}$ & 93 & 138 & 147 & $\begin{array}{l}\text { From } 15.04 .2020 \text { to } \\
03.05 .2020\end{array}$ & 133 & 207 & 250 \\
\hline
\end{tabular}

Table 2: $\mathrm{AQI}_{\text {avg }}$ of top polluted cities during outbreak of COVID-19, Janta Curfew, lockdown in 2020 and during same period of 2019 (CPCB, 2020). 


\section{Acknowledgements}

The Government of India is thankfully acknowledged for nationwide complete lockdown which impact on environment is the base for this paper. Authors are thankful to Deputy Director General and Head of the Department and other Higher Officials of GSI, WR for their continuous support and encouragement to think out of box. Central Pollution Control Board (CPCB) and Indian Meteorological Department (IMD) are sincerely acknowledged for providing online free AQI data. Authors are also grateful to every Indian citizen who were quarantine and stayed at their home during current pandemic of COVID-19 and lockdown. The anonymous journal reviewers are sincerely thanked for their fruitful comments and insightful suggestions.

\section{References}

Banerjee, D., Chakraborty, S.K., Bhattacharyya, S., Gangopadhyay, A., 2008. Evaluation and analysis of road traffic noise in Asansol: An industrial town of Eastern India. International Journal of Environmental Research and Public Health. 5, 3, 165-171. doi: 10.3390/ijerph5030165.

Basner, M., Babisch, W., Davis, A., Brink, M., Clark, C., Janssen, S., Stansfeld, S., 2014. Auditory and non-auditory effects of noise on health. The Lancet. 383, 9925, 1325-1332. https://doi.org/10.1016/S0140-6736(13)61613-X.

Burnett, R. T., Pope III C. A., Ezzati, M., Olives, C., Lim, S. S., Mehta, S., Shin, H. H., Singh, G., Hubbell, B., Brauer, M., Anderson, H. R., Smith, K. R., Balmes, J. R., Bruce, N. G., Kan, H., Laden, F., Prüss-Ustün, A., Turner, M. C., Gapstur, S. M., Diver, W. R., Cohen, A., 2014. An Integrated Risk Function for Estimating the Global Burden of Disease Attributable to Ambient Fine Particulate Matter Exposure. Environmental Health Perspectives, 122, 4, 397 403.

Cohen, A.J., Brauer, M., Burnett, R., Anderson, H.R., Frostad, J., Estep, K., Balakrishnan, K., Brunekreef, B., Dandona, L., Dandona, R., Feigin, V., Freedman, G., Hubbell, B., Jobling, A., Kan, H., Knibbs, L., Liu, Y., Martin, R., Morawska, L., Pope, C.A ${ }^{\text {3rd }}$, Shin, H., Straif, K., Shaddick, G., Thomas, M., van Dingenen, R, van Donkelaar, A., Vos, T., Murray, C.J.L., Forouzanfar, M.H., 2017. Estimates and 25-year trends of the global burden of disease attributable to ambient air pollution: an analysis of data from the Global Burden of Diseases Study 2015. The Lancet. 389, 10082, 1907-1918. https://doi.org/10.1016/S0140-6736(17)30505-6.

CPCB, 2018. Central Pollution Control Board, India, Annual Report. https://cpcb.nic.in/annualreport.php. (Accessed May, 2020).

CPCB, 2020. Central Pollution Control Board, India. https://app.cpcbccr.com/AQI_India/ (Accessed May, 2020).

Diem JE, Hursey MA, Morris IR, Murray AC, Rodriguez RA., 2010. Upper-level atmospheric circulation patterns and ground-level ozone in the Atlanta metropolitan area. Journal of Applied Meteorology and Climatology. 49(11):2185-2196. 
Diem, J. E., Stauber, C. E., Rothenberg, R,. 2017. Añel, Juan A. (ed.). Heat in the southeastern United States: Characteristics, trends, and potential health impact". PLOS One. 12 (5): e0177937. doi:10.1371/journal.pone.0177937. ISSN 1932-6203.

Fan, Y., Zao, K., Shi, Z.L., Zhou, P., 2019. Bat Coronaviruses in China. Viruses, 11, 210; doi:10.3390/v11030210.

Gebra, C.P., Betancourt, W.Q., 2017. Viral Aggregation: Impact on Virus Behavior in the Environment. Environ. Sci. Technol. 51, 7318-7325. DOI: 10.1021/acs.est.6b05835.

Gettleman, J., Schultz, K. (24 March 2020). "Modi Orders 3-Week Total Lockdown for All 1.3 Billion Indians". The New York Times. ISSN 0362-4331.

Gupta, M., Singh, S., 2016. Factorizing the Changes in $\mathrm{CO}_{2}$ Emissions from Indian Road Passenger Transport: A Decomposition Analysis. Studies in Business and Economics, 11(3), 67-83. doi:10.1515/sbe-2016-0036.

IMD, 2020. India Meteorological Department. https://mausam.imd.gov.in/(Accessed May, 2020).

India State-Level Disease Burden Initiative Air Pollution Collaborators, 2019. The impact of air pollution on deaths, disease burden, and life expectancy across the states of India: the Global Burden of Disease Study 2017. The Lancet Planetary Health, 3, 1, e26-e39. https://doi.org/10.1016/S2542-5196(18)30261-4.

Kampa, M., Castanas, E., 2007. Human health effects of air pollution Environmental Pollution. 151. 362-367. doi: 10.1016/j.envpol.2007.06.012.

Koonin, E.V., Senkevich, T.G., Dolja, V.V., 2006. The ancient Virus World and evolution of cells. Biology Direct. 1 (1): 29. doi:10.1186/1745-6150-1-29.

Landrigan, P.J., Fuller, R., Acosta, N.J.R., Adeyi, O., Arnold, R., Basu, N., Baldé, A.B., Bertollini, R., O’Reilly, S.B., Boufford, J.I., Breysse, P.N., Chiles, T., Mahidol, C., Coll-Seck, A.M., Cropper, M.L., Fobil, J., Fuster, V., Greenstone, M., Haines, A., Hanrahan, D., Hunter, D., Khare, M., Krupnick, A., Lanphear, B., Lohani, B., Martin, K., Mathiasen, K.V., McTeer, M.A., Murray, C.J.L., Ndahimananjara, J.D., Perera, F., Potočnik,J., Preker,A.S., Ramesh, J., Rockström, J., Salinas,C., Samson, L.D., Sandilya, K., Sly, P.D., Smith, K.R., Steiner, A., Stewart, R.B., Suk, W.A., van Schayck, O.C.P., Yadama, G.N., Yumkella, K., Zhong, M., 2017. The Lancet Commission on pollution and health. 1-51. http://dx.doi.org/10.1016/S0140-6736(17)32345-0.

MoEF 1981 Act. Ministry of Environment and Forests, Government of India, No. 14 of 1981, The Air (Prevention and Control of Pollution) Act, 1981, amended 1987. http://moef.gov.in/wpcontent/uploads/2018/03/No_14_1981.pdf (Access May, 2020).

Mumford, J. L., He, X. Z., Chapman, R. S.., Cao, S. R., Harris, D. B., Li, X. M., Xian, X. L., Jiang, W. Z., Xu, C. W., Chuang, J. C, Wilson, W. I., and Cooke, M., 1987. Lung cancer and indoor air pollution in Xuan Wei, China. Science 235: 217-220.

NEERI, 2013. National Engineering Environmental Research Institute, Annual Report 2012-13. https://www.neeri.res.in/archives/annual_reports (Accessed April 2020).

Oishi, N., Schacht, J. 2011. Emerging treatments for noise-induced hearing loss. Expert Opin Emerg Drugs. 16(2): 235-245. doi: 10.1517/14728214.2011.552427.

Pandya, G.H., Dharmadhikari, D.M., 2010. A Comprehensive Investigation of Noise Exposure in and Around an Integrated Iron and Steel Works. AIHA Journal. 62, 2002, 2. https://doi.org/10.1080/15428110208984701.

Peeri, N.C., Shrestha, N., Rahman, M.S., Zaki, R., Tan, Z., Bibi, S., Baghbanzadeh, M., Aghamohammadi, N., Zhang, W., Haque, U., 2020. The SARS, MERS and novel coronavirus (COVID-19) epidemics, the newest and biggest global health threats: what lessons have we learned? International Journal of Epidemiology, 1-10 doi: 10.1093/ije/dyaa033. 
Priyali, S., Ben, W. (28 March 2020). "Indian migrant workers face tough choice amid world's largest lockdown". CNN. Retrieved 28 March 2020.

Salk, J. E.; Gori, J. B., 1960. A review of theoretical, experimental, and practical considerations in the use of formaldehyde for inactivation of poliovirus. Ann. N. Y. Acad. Sci. 83, 609-637.

Sinha, S., Sridharan, P.V., 2003. Present and future assessment of noise level in the Neyveli region. Journal of Environmental Studies and Policy, 2(1), 1-13.

The Hindu Business Line, 2020. Covid-19 lockdown estimated to cost India \$4.5 billion a day: Acuité Ratings". 2 April 2020. Retrieved 11 April 2020.

Venkataraman, C., Brauer, M., Tibrewal, K., Sadavarte, P., Ma, Q., Cohen, A., Chaliyakunnel, S., Frostad, J., Klimont, Z., Martin R. V., Millet D. B., Philip S., Walker, K., Wang, S., 2018. Source influence on emission pathways and ambient $\mathrm{PM}_{2.5}$ pollution over India (2015-2050). Atmos.

Chem.

Phys.,

18 ,

8017-8039, https://doi.org/10.5194/acp-18-8017-2018.

Wikipedia, 2020. https://en.wikipedia.org/wiki/COVID-19_pandemic_lockdown_in_India. (Accessed May 2020).

Wikipedia, 2020. https://en.wikipedia.org/wiki/Atmosphere\#Composition. (Accessed April 2020).

WHO, 2016. WHO Global Urban Ambient Air Pollution Database. https://www.who.int/phe/health_topics/outdoorair/databases/cities/en/. (Accessed April 2020).

WHO, 2018. https://www.who.int/health-topics/air-pollution\#tab=tab_1. (Accessed April 2020).

WHO, 2020. https://covid19.who.int (Accessed May 2020).

World Resources Institute Climate Analysis Indicators Tool (WRI CAIT 4.0, 2017). GHG emissions are expressed in units of carbon dioxide equivalents. Global Warming Potentials (GWPs) are the 100-year GWPs from the Intergovernmental Panel on Climate Change (IPCC) Second Assessment Report (SAR). https://www.climatewatchdata.org. Accessed April, 2020. 